\title{
Financial Fragility, Bubbles and Monetary Policy
}

\author{
Gerhard Illing ${ }^{1}$
}

December 2001

\begin{abstract}
The paper models the links between financial fragility, asset markets and monetary policy. It is shown that central bank's concern about the cost of financial disruption may generate an asymmetric response, thus contributing to the creation of an asset price bubble. In an economy with a highly leveraged financial structure, the central bank has an incentive to prevent a "run" on financial intermediation by injecting liquidity when asset values fall significantly. The inflationary side effect of this policy, reducing the real value of nominal debt, is what gives rise to a "put option" for investors. Leveraged investors, rationally anticipating this liquidity injection, drive asset prices above their fundamental values. The bubble will be equal to the expected value of capital gains on outstanding debt. The paper shows that it is rational for central banks to inject liquidity in a crisis, whenever there is the risk of spillover effects arising from the disruption of financial intermediation.
\end{abstract}

Key words: Asset Bubbles , Monetary Policy, Financial Stability

JEL classification: E 5, G 2

\footnotetext{
${ }^{1}$ University of Munich, email: Gerhard.Illing@lrz.uni-muenchen.de I would like to thank Charles Goodhart, Korbinian Ibel, Ulrich Klüh, Axel Lindner, Adam Posen and an anonymous referee for comments on previous versions of the paper, as well as to seminar participants at the CESifo conference on Issues regarding European Monetary Union, at the Technical University in Vienna, at the 2001 European Meeting of the Econometric Society and the EEA meeting 2001 both in Lausanne and at the 2001 meeting of the Verein für Socialpolitik in Magdeburg.
} 
Mr. Greenspan's confidence that he can use monetary policy to prevent a deep recession if share prices crash exposes an awkward asymmetry in the way central banks respond to asset prices. They are reluctant to raise interest rates to prevent a bubble, but they are quick to cut rates if financial markets tremble. Last autumn, in the wake of Russia's default and a slide in share prices, the Fed swiftly cut rates, saying it wanted to prevent a credit crunch. As a result, share prices soared to new highs. The Fed has inadvertently created a sort of moral hazard. If investors believe that monetary policy will underpin share prices, they will take bigger risks. Economist 25-Sep-99

\section{Introduction}

The past decade has been characterized by a steady and sustained decline of inflation rates to an unprecedented low level. At the same time, however, there has been a dramatic surge in asset prices, followed by increasing volatility. Many economists consider at least part of this rise as a bubble with possibly damaging effects, with monetary policy itself as one factor responsible for generating bubbles.

In the US, for a long time, monetary policy paid attention to movements in stock prices. Alan Greenspan has frequently been blamed for having contributed to a bubble in the US stock markets by reacting asymmetrically to movements in stock prices (compare the quote above). Both in 1987 and during the crisis triggered by the collapse of the hedge fund Long term Capital Management (LTCM) in 1998, the Fed eased monetary policy fast, aiming to prevent a credit crunch, whereas it did not react to dampen the boom on the stock market or even try to prick a supposed bubble. This asymmetry, it is argued, gives investors the feeling that monetary policy works like a put option on the stock index, encouraging quasi-rational exuberance (see Miller/Weller/Zhang (2002)): Being confident that monetary policy will bail them out in a crash, investors feel safe to put their funds in more risky assets, thus creating a bubble. The central objective of this paper is to analyze to what extent such central bank behavior might be rationalized and to assess its consequences.

\subsection{Banking vs. Securitisation - A brief survey of the financial structure in the Euro-area}

Whereas in the US, movements in stock prices are considered to be an important factor for predicting monetary policy, the stock market has been of much less concern in the Euro-area in the past. One reason for this may be the sharp differences in financial structure between the two economies: In the Euro-Area, bank loans are the dominating source of finance. In Germany loans represent $50 \%$ of non-financial companies' liabilities, whereas securitized liabilities (equity and bonds) have a share of less than $20 \%$ (see figure 1 in the appendix). In 
remarkable contrast, with a share of $72,2 \%$ they are the dominating source of finance in the US (the share of banking being just 15\%). In the US, institutional investors take the role which is played by banks in the Euro-area, as pointed out by Davis (2000). What are the consequences of these differences? Firstly, in an economy with a small part of financial wealth in the form of equity, wealth effects of stock prices (a controversial issue even in the US, see Bernanke /Gertler (1999)) should not have a significant impact on the transmission mechanism. Secondly, balance sheet effects - the most prominent propagator of asset price changes to the real economy - may loose part of their impact, since a financial system with relationship lending may reduce the amount of asymmetric information central to these phenomena. For similar reasons, exposure to systemic risk arising from a collapse of asset prices used to be much lower in the Euro-area.

In this paper, we argue that convergence in financial structure between the US and the Euroarea may change this pattern in monetary policy making. Surprisingly - and contrary to conventional wisdom - there has been no major evidence for such a trend during the past decade. In a detailed empirical analysis, Schmidt/Hackethal/Tyrell (1997) found in Germany neither a general trend towards disintermediation, nor towards a transformation from bankbased to capital market-based financial systems, nor for a loss of importance of banks (compare also figures 3 and 4). During recent years, however, signs of a significant change point to an end of the quiet times in Euroland. Equities and - to a lesser extent - bonds become more important both as means of external finance (figure 4) and as component of financial wealth (figure 3).

Even though the identification of such trends is complicated due to intra-European divergences and lack of consistent data (so figures 3 and 4 have to be handled with care), we see major signs pointing in this direction. In Germany, for example, the IPO of Deutsche Telecom end of 1996 and the opening of the "New Market" in March 1997 gave a big push to share holding (see figure 5): Certainly still much lower than in the US, the percentage of individuals holding shares doubled from $8.9 \%$ in 1997 to $17,7 \%$ in 2000 . As shown in figure 6 , this rise is mainly due to equities held in the form of investment fund certificates. Together with the strong growth both in market capitalization and in the number of listed stocks (figure 2), this evidence suggests an increasing role for equity markets as part of the financial system. It is also supported by some micro-trends, such as the increase in venture capital finance in the Euro-area, as pointed out by the Bundesbank (Monthly Bulletin October 2000). 
Developments in the market for corporate bonds are somewhat less clear cut. Since the start of the new currency, issues in Euro (as compared to its predecessor currencies) have reached long-time highs, admittedly starting from an extremely low level. As noted in this years $B I S$ annual report (2000, page 129), "the composition of borrowers that have tapped the euro bond market partly reflects the traditional structure of European finance, but partly also its changing profile". Compared to issues by European banks, the share of bonds issued by nonfinancial corporations is still small, but growing. The telecommunications sector plays a key role. It financed large parts of its huge investments through bond issues, contributing to a concentration of credit risk in this sector.

Starting from the observation of probably converging, but still heterogeneous financial market structures, one may suspect that asset prices should follow distinct patterns in the US and Euroland. But co-movements of stock prices in the two areas are a stylized fact of international equity markets. In particular shares of new-economy firms experienced unusually large price increases in both markets (see figure 7). Contrary to conventional wisdom, at some stage price hikes of shares listed in the German Nemax index became even more pronounced than those in Nasdaq. These hikes were followed by equally pronounced collapses in recent months. It thus seems that both economies experienced swings in share prices of a possibly damaging magnitude (figures 7 and 8).

Such volatility may have damaging effects if the economy (i.e. borrowers and financial institutions) is sufficiently exposed to asset price risk. Although marginal investors in new economy shares experienced large losses in recent months (figure 7), the real economy does not seem to be hit until now. So exposure to asset price risk does not seem to be of much concern. We argue that such reasoning may be premature. Take the telecommunication sector, which provides a perfect example for the theoretical analysis of this paper: Recent doubts whether telecom firms will be able to generate sufficient cash-flows to justify highly leveraged investments and high share prices (figure 8) already had an impact on financial stability: In the US, they contributed to the recent drying out of the high yield bond market. In Europe, several regulatory institutions expressed concerns about over-exposure of banks to this sector.

Real estate is another market where highly leveraged transactions are a common phenomenon. Not only the experience of Japan shows that policymakers should pay special attention to this sector. Even though some urban areas in the US experienced exceptionally large increases since 1995, there are no signs of a pronounced bubble for commercial or residential property 
in the US market. The same holds true for Europe on an aggregate level. Here, the biggest markets are only starting to recover from times of oversupply since the late eighties. However, on a national level, countries like Ireland or the Netherlands already show signs of overheating, manifesting themselves in fast credit growth and exploding prices, and indicating the need for a close monitoring by the monetary authority (see figure 9 for an overview).

The ECB has to be prepared to the trends outlined above: the increasing importance of securatized liabilities, especially shares, and rising volatility in asset markets in fact already have impacted monitoring activities, as evidenced by a recent ECB (2000) study on "Asset prices and banking stability". But monitoring may not be enough. In the future, the ECB (as well as other central banks) have to answer questions about the role asset prices should play in formulating monetary policy.

\subsection{Monetary Policy and Asset Prices}

The striking contrast between price stability for consumer goods and "inflation" of asset prices has recently stimulated research in the role of asset prices for monetary policy. Two issues are at the center stage of the discussion:

(a) Are rising asset price a useful predictor for future inflation? Might stronger attention to asset price movements contribute to price stability by improving the performance of inflation forecasts? According to conventional wisdom, central banks should - and do - pay attention to asset prices only to the extent that they are an indicator for inflationary pressure. Recently, however, a CEPR report by Cecchetti/ Genberg/ Lipski/ Wadhwani (2000) strongly argued that asset prices should be included in the Taylor-rule as a separate element. As long as asset prices as forward looking variables provide reliable information ${ }^{2}$, including them in a reaction function is likely to improve performance relative to a traditional, backward looking Taylor rule. This is mainly an empirical issue: Starting with Bernanke/Gertler, a number of papers simulated the performance of various reaction functions when an economy is exposed to a stochastic bubble. So far, however, the evidence is rather mixed: It depends on the

\footnotetext{
${ }^{2}$ Monetary policy, however, first has to solve a much deeper problem: to identify what type of information is driving changes in asset prices. This is essentially a signal extraction problem about the type of shocks: If asset prices are rising as a consequence of good news signaling a permanent positive supply shock with substantially improved growth potential, say in the new economy sector, there may be no inflationary pressure at all, and so no need to react. If, on the other hand, rising prices are the result of a pure bubble generated in the financial sector, it may indicate both inflationary pressure from short run wealth effects and the risk of high volatility when the bubble will burst eventually in the future, both calling for strong reactions. Again, things may be quite different when private agents adjust to the presence of a bubble by dampening consumption and limiting exposure to credit expansion (see Cogley (1999) and Smets (1997)).
} 
precise functional specification used, whether inclusion of asset prices helps to improve the performance (compare Bernanke/Gertler (1999), Cecchetti et al. (2000) and Batini /Nelson (2000).

(b) Does monetary policy itself contribute to the creation of bubbles? Central banks are expected to provide liquidity in order to prevent financial instability triggered by a crash on stock markets. Thus, anticipating an asymmetric response, investors may be encouraged to overinvest in risky activities.

The Cecchetti-CEPR report proposes to avoid this asymmetry by including asset prices explicitly in a modified Taylor rule. Since such a rule would commit central banks to respond symmetrically to asset price movements, it would - so they claim - tackle both issues discussed at the same time. By dampening asset price misalignments, such misalignments would be less likely to occur right from the beginning, and their magnitude would be likely to be smaller. This suggestion is not convincing for at least two reasons: First, the optimal response crucially depends on the nature of the shock causing movements in asset prices. So it can never be optimal to bind the central bank to a mechanical rule, committing it to respond in a predetermined, symmetric way to changes in asset prices. Evidently, efficient policy requires a careful analysis of the specific type of shocks underlying any price change. Quarrels about the extent of misalignments leave plenty of room for discretionary arguments. ${ }^{3}$

Second, in the approach used by Cecchetti et al. (2000), one key reason for the supposed asymmetric response is not modeled at all: Concerns about financial stability, which are at the center of the argument, are not included. The authors simulate the effect of a bubble in a Bernanke/Gertler type dynamic New Keynesian model with financial accelerator effects. As already pointed out by Dornbusch (1999), the structure of this model focuses exclusively on variations in risk premia and so misses a crucial element of the story - the risk of a breakdown of the whole system arising from financial fragility: ${ }^{4}$ "once markets crash,... markets plain stop in terms of flow and rollovers and, thus, within a short period, risk

\footnotetext{
${ }^{3}$ See Smets (1997) and also Issing (1998) and Cogley (1999). One problem is that it may be too late to act without triggering a crisis when the bubble becomes evident. Take the crash in 1929 for illustration. It is often cited as an example that a policy of easy money before the crash contributed to the bubble, since the Fed failed to take deliberate action to puncture the bubble. But as shown by Cogley (1999), starting in 1928, the Fed shifted toward increasingly tight monetary policy, motivated in large part by a concern about speculation in the stock market. The depth of the contraction had much to do with the fact that the Fed continued a tight money policy after the crash, aiming to contain moral hazard.

${ }^{4}$ Such crashes may be the result of a bursting bubble or of bad news about aggregate shocks to the economy. In this paper, we analyze the latter case. We show that concerns about stability is a separate factor contributing to a bubble. A modified Taylor rule would be of no help in that case.
} 
inducing pervasive default. Here, big rate cuts and housing markets with cheap credit, not many questions asked are essential (Dornbusch (1999))."

The present paper aims to shed light on exactly this aspect. In a crisis, the central bank's policy objective is to prevent the disruption of financial intermediation. The central bank is not concerned with preventing stock market crashes as an end in itself. Obviously the policy response will depend on the financial structure of the economy, and so there is a need to model explicitly the degree of financial fragility. Since a crucial element for any analysis of central bank's reaction to crashes is the exposure of the whole economy to financial fragility, this paper models explicitly the link between financial fragility and monetary policy. This requires a set up mixing elements of micro- and macro analysis.

\subsection{Outline of the paper and related literature}

We consider an economy with two sectors: investment in the old economy sector is safe, whereas investment in the other sector, the new economy, is risky. Given the observational equivalence between the bursting of a bubble and bad news about real shocks, usually it is extremely hard (except for the model builder) to identify the existence of a bubble even ex post. Rather than assuming that pure bubbles may burst with some exogenous probability, we model a crash as a rational response to bad news about profitability of firms in the new economy sector. Following Allen/Gale (2000), we define "bubbles" in the following precise sense: Due to overinvestment in the risky sector, the asset price in that sector - the rent of the scarce resources - is driven up above its fundamental value. So the bubble is modeled as the distortion of the relative price of an asset.

As the key factor for monetary policy actions, we single out financial fragility. As long as equity is the main source finance of risky activities, leverage effects are small, and so risk of disruption is low. In that case, there is no need for monetary policy intervention when the stock market crashes, since there is no risk of early liquidation and disruption of the whole economy.

In contrast, with a highly leveraged financial structure, characterized by high debt exposure to intermediaries, a crash triggers a "run" on intermediaries, resulting in the disruption of intermediation and costly early liquidation of real assets in the absence of central bank intervention. The central bank is concerned about the destruction of the information capital specific to the banking sector (the expertise gained from relationship-lending). By providing sufficient liquidity, monetary policy can prevent disruption of intermediation, thus enabling 
the restructuring of solvent, but illiquid firms (compare the policy during the LTCM crisis vs. the policy in Japan beginning of the 90's).

Since inflation reduces the real value of nominal debt, those firms surviving do enjoy capital gains. Investors rationally anticipate these capital gains. This drives up the asset price above the fundamental value, thus creating a bubble equal to the expected value of capital gains out of central bank's rescue operations. The bubble is equal to the expected value of capital gains on outstanding debt.

A variety of economic mechanisms may create a bubble. In the paper, we consider the following three mechanisms: (1) Irrational exuberance of investors; (2) Weak financial intermediation: Weak monitoring may allow investors to appropriate the gains out of risky investment and shift part of the losses to the fnancial sector. (3) Central bank's concern about financial stability may work as a kind of put option for risky activities. ${ }^{5}$

The first two effects have been documented extensively in the literature. The next section briefly illustrates both effects within a simple model. First, we characterize the fundamental value of the asset and then demonstrate how irrational exuberance and weak monitoring may create bubbles. Since financial stability issues are not essential for these two cases, we abstract from liquidation costs in that part of the paper in order to analyze the issue in the most simple set up. The model is closely related to the work of Allen/Gale (2000a); we present a condensed version of their approach.

Using this setup as a starting point, in section 3, in the core part of the paper, we then analyze the impact of central bank's concern about financial stability. This aspect has recently become a topic hotly debated among central bankers and financial market participants. But, as far as we know, it has not yet been modeled explicitly up to now, since no tractable framework has been available for analyzing this issue. We present a very simple, stylized model illustrating conditions under which monetary policy may create such a bubble and analyze the rationality behind such a policy.

The risk of a run triggering inefficient liquidation of projects plays a key role for financial stability. Following Allen/Gale (2000b), we introduce aggregate risk into the standard Diamond/Dybvig bank run model: When the new economy is hit by such an aggregate shock,

\footnotetext{
${ }^{5}$ Of course, in reality, asset prices are driven by a combination of all three mechanisms. So Miller et. al (2000) argue that the Fed's policy has the effect to give each investor on the stock market the - false- impression of providing a put option allowing him to get out first before the stock market crashes. Effectively, Miller's model amounts to nothing else than assuming overconfidence. They do not analyze central bank behavior at all.
} 
depositors will run the banks, and all projects have to be liquidated unless the central bank provides sufficient liquidity. Again, the approach is closely related to work by Allen/Gale. They, however, do not model mechanisms by which monetary policy may create bubbles. In particular, they do not analyze central bank's trade off's involved with such a policy. In contrast, we characterize costs and benefits of central bank's rescue operations.

\section{Bubble creating mechanisms}

\subsection{The basic model}

The set up of the model is a modified and drastically simplified version of Allen/Gale (2000a). There are two sectors: Investment in the old technology sector $\mathrm{Y}$ is assumed to be riskless. Projects yield a safe return. Investment in the safe sector yield a gross return $1+\mathrm{r}$.

In the new economy sector $\mathrm{X}$, investment is risky - when projects turn out to be successful (with probability $\mathrm{q}$ ), they yield a high return $R$. But (with probability $1-\mathrm{q}$ ), they also run the risk of failure. In case of failure the return is low $C<1+r<R$. $^{6}$

To simplify, the supply of risky projects is assumed to be fixed. It should be interpreted as the- in the short run - inelastic supply of scarce skills in human wealth, of those being capable to design new economy projects (innovators with entrepreneurial spirits, but lacking the capital to found start up firms). (Alternatively, the fixed asset may be viewed as land, modeling bubbles in land prices). Whereas each innovator has a measure of 0 , the aggregate supply of new economy projects has measure 1 .

In the economy, there are 4 types of agents: (1) The innovators, supplying risky projects for the new economy. (2) Venture capitalists with own funds $\mathrm{E}$ which they can either use as equity in the new economy or for investment in the old economy. Since they have the specific knowledge to evaluate projects in the new economy, they can fund these projects as venture capitalists in start up firms. (3) Depositors willing to invest their wealth $\mathrm{W}$ for future consumption. Depositors supply these funds inelastically. They do not, however, have the expertise to act as venture capitalists, and so can invest only via deposits at banks. (4) Finally, investment of depositors is channeled to the firms via a competitive banking industry. Both banks and venture capitalists are assumed to be risk neutral.

\footnotetext{
${ }^{6}$ Later, in section 3, when we analyze the risk of runs, early liquidation of projects is assumed to be costly. The liquidation value is below the continuation value: $L<C$.
} 
The price of the risky asset is $P_{X}$. The aggregate supply of funds is $W+E$. Since the availability of the risky asset is normalized to $X=1$, the aggregate constraint on investment and saving is:

$Y+P_{X} X=Y+P_{X}=W+E$

Under full information, in the absence of distortions, the asset price is equal to the present value of expected returns. An asset price bubble occurs whenever the market price exceeds this fundamental value. The bubble has distortionary effects on the economy: The higher the asset price of the risky sector, the lower the funds available to be invested in the old economy sector, thus reducing aggregate production.

Since supply of new economy projects is assumed to be fixed in the short run, the distortion here manifests itself as a pure rent captured by the innovators: The bubble redistributes resources towards these innovators. Using a utilitarian approach, behind the veil of ignorance (at a stage before agents know whether they will be innovators, venture capitalists or depositors), the welfare maximizing rent is equal to the present value of expected returns; any deviation from this price causes distortions. ${ }^{7}$

\subsection{The fundamental value of the asset}

As a reference point, we first consider the allocation in the case of perfect financial markets. Let us assume initially that investment in the risky sector is purely equity financed. For each unit invested, the gross return is $\frac{q R+(1-q) C}{P_{X}}$. So in equilibrium, the following arbitrage equation must hold:

$$
1+r=\frac{q R+(1-q) C}{P_{X}}
$$

The asset price is equal to the discounted expected present value of the risky asset:

$$
P_{X}^{*}=\frac{q R+(1-q) C}{1+r}
$$

\footnotetext{
${ }^{7}$ It would be straightforward to generalize the results to an economy with endogenous supply of new economy projects. Then, any bubble will also produce an excess supply of risky projects above the efficient level.
} 
$P_{X}^{*}$ is the fundamental value of the asset. As illustrated below, in an economy with efficient intermediation the asset is priced at this value.

\subsection{Irrational exuberance}

When investors are overconfident, their subjective perception of future returns of the asset will be upward biased. Whereas, for a long time, it used to be unpopular to blame bubbles on pure irrationality, behavioral finance recently gave a variety of sound scientific motivations for this phenomenon. In the set up here, all these stories essentially can be captured by the subjective overestimation either of the good return $R$ or of the success probability $q$. An overestimation $\hat{R}>R$ creates the following bubble:

$$
P_{\hat{X}}=\frac{q \hat{R}+(1-q) C}{1+r}>P_{X}^{*} \text { with } P_{\hat{X}}-P_{X}^{*}=\frac{q(\hat{R}-R)}{1+r}
$$

Recent research provides sophisticated arguments for this phenomenon, such as herding behavior of institutional investors. With heterogenous agents (some of those being less overconfident), the absence of short sales is a crucial condition to prevent realization of arbitrage possibilities. A serious shortcoming of this way to explain bubbles is the observationally equivalence between overconfidence and favorable new information: Good news about the profitability of the new economy sector will lead to a revision of forecasts about the investment return. The asset price is exactly the same as in the bubble characterized above, if forecasts are revised upwards by $\hat{R}-R$. Ex post, once an aggregate crash occurred, there is no way to distinguish between these two explanations.

\subsection{Real bubbles arising from weak financial intermediation}

Above, we showed that the asset price is determined by the expected present value when investment is financed by equity, unless there is overconfidence among investors. In general, however, investors do not have enough equity and need credit to finance investment in the new technology. In this section, for simplification (without loss of generalization), we consider only the (interesting) case that the return in the bad state is not sufficient to cover gross debt payments $C<(1+r)\left(P_{X}-E\right)$, so investors will be bankrupt when the project fails. $C$ can be seen as the collateral investors are able to pledge to the bank. 
Obviously, credit contracts may give investors an incentive for risk shifting to the financial sector, making use of the leverage effect. So financial intermediaries are facing a monitoring problem: the lower the equity share of investors, the higher the risk for the bank. Allen/Gale (2000a) have shown that weak financial intermediation can create a "real bubble". They assume that banks are not able to monitor how investors allocate their funds across the two sectors. This gives investors a strong incentive for excess investment in the risky sector. As a result of the monitoring problem, the asset price is driven above its fundamental value.

In this section, we illustrate the effects in an extremely stylized version of the Allen /Gale model, highlighting the economic mechanism behind. In their model, investors are assumed to have no own funds. We allow for equity of investors and show that the bubble occurs as long as equity plus collateral is less than the fundamental value of the asset. The bubble is a direct implication of the leverage effect of credit finance. In the two state version of the model presented here, this can be illustrated in a straightforward, intuitive way: Under credit finance, when intermediaries cannot monitor investment, the asset price is driven up to the present value of returns in the good state.

As the most drastic example of inefficient monitoring, let us now assume that banks cannot condition lending on the share of equity invested in the new economy sector. They cannot observe in which sector investors put their funds and are not able to claims investor's equity invested outside of the project. Again, the own rate of return for investors must be equal across both sectors. With credit finance, return to the investor increases with increasing credit finance as a consequence of the leverage effect:

$q R+(1-q) C-q(1+r)\left[P_{X}-E\right]-(1-q) C=(1+r) E$

Monitoring problems drive up the asset price $P_{X}$ (the rent to the scarce resource) to:

$$
\begin{aligned}
& P_{X}=\frac{R}{1+r}-\frac{1-q}{q} E \\
& P_{X}>P_{X}^{*} \text { for } \frac{q(R-C)}{1+r}>E
\end{aligned}
$$

Using the definition of $P_{X}^{*}$, this condition is equivalent to $P_{X}^{*}>\frac{C}{1+r}+E$. There is a bubble whenever outside finance is needed, that is investor's equity, plus the present value of the 
collateral $\mathrm{C}$ which can be pledged, is not sufficient to cover the fundamental value. Because of the monitoring problems, banks are not able to make claims on the investor's equity invested in the old economy sector. Thus, whenever investors apply for outside funds, it will always be optimal for them to put all own funds in the old economy. Investment in the new economy is then financed purely via credit - so as to make best use of the leverage effect. Consequently, no equity finance will be used for investment in the new economy. With $E=0$, the asset price is driven up to

$$
P_{X}=\frac{R}{1+r}
$$

$P_{X}$ is equal to the present value in case the project turns out to be successful, since investors care only for that case. The bubble component amounts to:

$$
P_{X}-P_{X}^{*}=\frac{(1-q)(R-C)}{1+r}
$$

It is straightforward to see that the "bubble" is increasing with the riskiness of the new sector. Consider a mean preserving spread of the asset return, leaving expected return $q R$ unchanged. Such a spread reduces probability of success $q$, but increases the return $R$ of the project and so raises the asset price $P_{X}$.

As Allen/Gale argue, innovators receive an information rent when the banks cannot monitor. In the set up here, depositors supplying funds inelastically have to bear the cost. All the rent is captured by the owners of the scarce resource (the bubble is equal to the information rent). More generally, investors will get part of the rent via higher return to equity. In this section, we demonstrated the key insight by Allen /Gale using the simplest setup. We assumed that banks are not able to monitor how investors allocate their funds across the two sectors. Inefficient monitoring should best be seen as a simple representation of weak financial intermediation. When weak intermediation allows agents to transfer part of the risk to other agents in the economy, there will be excessive risk taking and bubbles.

Take, as an example, the East-Asian crisis, which frequently has been blamed on inefficiencies in the financial sector (possibly supplemented by implicitly relying upon a government guarantee to cover potential losses). The recent bubbles following Ponzi-game schemes in Albania and Rumania confirm the relevance of this argument. According to conventional wisdom, however, Western economies are characterized by highly efficient financial markets, designing sophisticated mechanisms to cope with monitoring problems. Nevertheless, plenty of real world examples demonstrate the role of lax intermediation in 
creating bubbles even in these sophisticated economies. Recent evidence following the failure of many new economy firms pinpoints to a serious distortion in the incentive structure for control (a prominent example being the case of Enron).

Obviously, efficient regulation of financial markets is a key element for preventing bubbles. Rather than assigning a task for monetary policy, this suggests that there is a strong need for improving regulation and supervision to ensure efficient monitoring. In the remaining part of the paper, however, we are concerned with the question to what extent monetary policy itself may create a bubble. For that purpose, we abstract from irrational exuberance and inefficient monitoring. So from now on, we will assume that banks are able to control investors exposure to the risky sector. First, we illustrate that no bubble arises in that case.

\subsection{No bubble under efficient monitoring}

When banks can control to what extent investors are exposed to the risky sector, they will charge a risk adjusted rate of return. For all funds invested in the new economy, the rate depends on the amount of equity invested by the creditor herself. Let $D=P_{X}-E$ be the debt exposure in the economy. Under efficient monitoring, for $C<D(1+r)$ the bank will charge a risk adjusted rate of return defined as

$q D(1+\hat{r})+(1-q) C=D(1+r)$

(for , $C>D(1+r)$, lending would be riskless, since debt payments could be financed out of collateral, and so $\hat{r}=r$ ). As arbitrage condition, the gross return in the new economy sector has to equal the gross return in the old economy:

$q R+(1-q) C-q(1+\hat{r})\left[P_{X}-E\right]-(1-q) C=q R+(1-q) C-(1+r)\left[P_{X}-E\right]=(1+r) E$

or:

$P_{X}=P_{X}^{*}=\frac{q R+(1-q) C}{1+r}$

Evidently, under efficient bank monitoring, when the credit rate is adjusted properly to the risk involved, the real bubble disappears and the asset price equals the fundamental value. We are back in the world of the Modigliani /Miller theorem. ${ }^{8}$

\footnotetext{
${ }^{8}$ Of course, principal agent problems may prevent the first-best solution. But when banks as principals choose the optimal monitoring technology (incentive compatible contracts to cope with moral hazard of investors), a second-best outcome will be obtained. It is likely to be characterized by constraining investment in the risky sector (like credit rationing) rather than overinvestment.
} 


\section{Financial stability concerns - Bubbles and monetary policy}

In this section, we analyze under what conditions central bank's concern for financial stability may contribute to a bubble. Concentrating on this aspect, we abstract in the following from other mechanisms like irrational behavior and monitoring problems. ${ }^{9}$ We present a highly stylized benchmark model with a simple micro structure capturing the risk of financial disruption.

\subsection{Restructuring under bank monitoring}

We now modify setup of the model presented in section 2 by introducing liquidation costs, making banks susceptible to runs. As in Diamond/Rajan (2000), banks play two important roles in the economy: First, they offer deposit contracts with nominal claims allowing for early withdrawal of funds. For simplicity, we do not model the demand for deposit contracts, but simply take them as given. Traditionally, the reason for these contracts is said to be the provision of liquidity insurance, as in Diamond/ Dybvig (1983) or Allen/ Gale (1998). Diamond/Rajan (2000) present a quite different, equally relevant motivation for deposit contracts: Under relationship-lending, the fragile structure is necessary to prevent banks from extracting private rents arising from its specific skills.

Secondly, banks monitor the firms they give loans to. Failing projects have a low liquidation value $\mathrm{L}$ if liquidated early. A share $\alpha$ of the failed projects, however, could recover a continuation value $\mathrm{C}>\mathrm{L}$, in case they were allowed to be restructured. Such restructuring requires replacement of management and monitoring by experts. When a firm gets into trouble, only its house-bank is capable to judge whether restructuring is worthwhile and to monitor the process of restructuring. When banks are forced into bankruptcy, however, this expertise is lost, and all firms will be liquidated.

The structure of the model is outlined in figure 10. We now consider 3 periods. In the first period, funds are allocated across the two sectors just as in section 2. In the new economy sector, successful projects yield a return $R$ in the final period. In the second, interim period 2, however, agents get a (fully informative) signal. It indicates those new economy projects which are going to fail. If these bad firms were forced to early liquidation during the interim period, they can only recover the liquidation value L. In contrast, if these firms are

\footnotetext{
${ }^{9}$ These factors - like over-expansion of bank credit arising from relaxed lending standards out of euphoria would aggravate the problem.
} 
restructured rather than being liquidated, they may recover the continuation value $\mathrm{C}$ in the final period.

Without monitoring, however, firms can recover $\mathrm{C}$ only with low probability $\beta$, but they will end up with no return at all (0) otherwise. We assume $\beta \mathrm{C}<\mathrm{L}$, so it would be inefficient to let the firms survive without restructuring. The managers, however, would have an incentive to continue operation, in an attempt to gamble for resurrection.

In contrast, due to its expertise out of relationship lending, the house-bank can distinguish between those firms which should be closed down and those for which restructuring is profitable. The latter (representing a share $\alpha$ of all failing firms) can recover the continuation value $\mathrm{C}$ for sure, provided they are monitored by their house bank. So under efficient restructuring, the average return of failing firms will be $\bar{C}=\alpha C+(1-\alpha) L$. Only the bank has the knowledge and experience to restructure those firm, by replacing the old management and monitoring the firm's performance until the final period. As in Diamond/Rajan (2000), the fragile financial structure (giving depositors the right to withdraw their funds in the intermediate period) prevents banks from extracting rents from their special skills due to relationship lending. Disruption of financial intermediation would lead to aggregate losses equal to $\bar{C}-L=\alpha(C-L)$

The setup is meant to capture key elements of financial vulnerability: (a) the bank liabilities are characterized by deposit contracts, fixed in nominal terms; (b) banks as financial intermediaries invest in illiquid risky long term assets (c) early liquidation is costly: the continuation value $\mathrm{C}$ exceeds the liquidation value $\mathrm{L}$. (d) disruption of financial intermediation destroys valuable information capital. ${ }^{10}$ As shown below, the difference C-L plays a crucial role in the analysis. C-L should best be interpreted as the degree of financial fragility of the economic system arising from forced disruption, rather than as simple liquidation costs of individual firms.

\footnotetext{
${ }^{10}$ When financial intermediation is disrupted, information capital is destroyed with possibly serious long term impact, as the experience in Japan during the last decade illustrates. The losses are aggravated by spillover effects to other institutions with similar exposure. The stronger the exposure within the financial system, the stronger these effects. So the failure of an intermediary is likely to generate externalities, triggering cascade effects across intermediaries. Incorporating these contagion effects into the model will be an important extension in future research.
} 


\subsection{The case of idiosyncratic risk}

We distinguish between two types of risk - idiosyncratic risk of individual firms and aggregate risk. For simplicity, we split the failure probability $1-\mathrm{q}$ in two parts: $1-q=s+(1-s-q)$

With probability $(1-s-q)$, the failure is due to pure idiosyncratic risk. A constant share $(1-s-q)$ of new economy firms is affected by the shock. Due to the law of large numbers, there is no uncertainty about aggregate resources. In that case, when firms are allowed to be restructured, expected aggregate returns paid to the bank are exactly equal to the nominal value $A$ of claims of depositors.

$A=Y(1+r)+q D(1+\hat{r})+(1-q-s) \bar{C}$

From the aggregate first-period budget constraint we know that:

$Y=W-\left(P_{X}-E\right)=W-D$

Furthermore, under efficient monitoring $D(1+r)=q D(1+\hat{r})+(1-q) \bar{C}$. So $A$ simplifies to:

$A=W(1+r)$

In the absence of an aggregate shock, aggregate returns flowing to the banks are equal to the nominal value of deposits. So banks are solvent, being able to pay back all depositors. As long as there is only purely idiosyncratic risk, no liquidity problem arises, since there is no reason for depositors to run - they can all safely cash in their deposit in period 3 to get the real return originally contracted for. Thus banks will not recall loans to those firms for which the value as a going concern exceeds the liquidation value. There is no costly disruption of long term investment.

\subsection{Aggregate shocks and financial fragility}

With probability $s$ an aggregate shock hits the whole new economy sector, with all firms failing. Now, the economy runs into a serious problem. ${ }^{11}$ When there are bad news about the aggregate prospective returns in the new economy, banks will not be able to pay out all

\footnotetext{
${ }^{11}$ Capital requirements and bank's equity could help to smooth small aggregate shocks. The paper, in a drastic simplification, intentionally introduces a large aggregate shock such that banks cannot take precautionary actions. It future work, the impact of capital requirements will be analyzed in a generalized framework with continuous rather than discrete shocks.
} 
depositors. Whenever, in the intermediate period 2, depositors get a signal that aggregate return will be less than the nominal claims of the deposit, they all have an incentive to run. This coordination problem results in costly inefficient liquidation of long term assets, possibly aggravated by externalities involved. Injection of aggregate liquidity could avoid a default of the banking sector. As long as the continuation value of the economy exceeds liquidation value, public provision of aggregate liquidity may prevent costly disruption.

Debt exposure in the economy is characterized by $D=P_{X}-E$. As long as investors have enough own funds (high equity finance) such that gross debt can be repaid even with early liquidation (that is $L>D(1+r)$ ), financial fragility is no problem. For low credit exposure of financial intermediaries, there is no need for intervention. For $L<D(1+r)$, two cases have to be distinguished: First we briefly discuss the case $D(1+r)<\bar{C}$. That is the case with illiquid, yet solvent banks: Aggregate expected return under efficient restructuring exceeds debt payments. Early liquidation triggered by a bank run would disrupt an inherent solvent economy. As in Diamond/Dybvig (1983), in the absence of intervention, there always exists a self-fulfilling equilibrium in which all depositors run. But we consider that case as being rather artificial. It can simply be eliminated by assertion of the central bank that it will be ready to provide enough liquidity. The announcement itself would be sufficient to prevent a run.

The much more interesting case is a debt exposure so high that the banking system would be insolvent even when allowing for the restructuring of new economy firms (that is, even when those firms which could recover $\mathrm{C}$ are allowed to survive, rather than liquidating them). From now on, we assume that $D(1+r)>\bar{C}$ (implying, of course, $D(1+\hat{r})>\bar{C}$ ).

\subsection{Bubbles and liquidity provision}

Whenever depositors observe an aggregate shock in period 1, indicating that the whole new economy sector is failing, a run on the banks will set in. A break down of the financial system will destroy the information capital built up by the banks via relationship-lending and thus force all firms to early inefficient liquidation. This can only be prevented, if the central bank is willing to provide sufficient aggregate liquidity. The central bank has to inject enough liquidity such that banks are able to satisfy liquidity demand of depositors. Following Allen/Gale (2000b), we model this process such that in case of a bank run, the central bank 
issues nominal claims to the banks, requiring that the money will be paid back in the last period.

In the absence of liquidity injection, the price evel in the economy is normalized to $P=1$. As in Allen/Gale (2000b), liquidity injection raises the price level in the economy, thus reducing the real value of nominal debt: $\frac{D(1+\hat{r})}{p}<D(1+\hat{r})$ whenever $p>1$. To avoid disruption of the system, the central bank has to provide enough liquidity to eliminate the risk of a run on banks. There is no incentive for depositors to run on banks when the liquidation value $L$ of new economy firms is sufficient to repay the nominal value of their claims. Thus, to eliminate any risk of a general bank run, the price level will have to rise up to:

$\frac{D(1+\hat{r})}{p}=L$

Since inflation reduces the real value of nominal debt, all restructured firms enjoy capital gains whenever inflation erodes the nominal value of the firms debt such that real repayment is less than the continuation value of the firm.

$\frac{D(1+\hat{r})}{p}<C$

When investors rationally anticipate these capital gains, the asset price is driven up ex ante above the fundamental value. This way, financial stability concerns create a bubble equal to the expected present value of capital gains out of central bank's rescue operations. Thus, the bubble is equal to the present expected value of this subsidy. The expected bubbles is rising with the crash probability $s$ and the firm's real return out of the central bank's rescue operation. As in section 2.2 and 2.3, the bubble raises the asset price above its fundamental value:

$B=P_{X}-P_{X}^{*}=s \alpha \frac{1}{1+r}\left(C-\frac{D(1+\hat{r})}{P}\right)$

In the model, the inefficiency caused by the bubble is represented by the output loss in the old economy sector. It is exactly equal to the bubble component $B$. The central bank has to trade off the cost of a rescue operation (the bubble created by moral hazard) against the risk associated with the disruption of financial intermediation. The expected gain of avoiding the break-down of the financial system is captured by two elements: first, the difference between 
continuation and liquidation value $C-L$ for the share $\alpha$ of successfully restructured firms, given the aggregate shock. Second, contagion effects spilling over to other sectors in the economy. The costs of these spillovers are likely to rise with the fragility of the economic system, so we assume that spillover costs $S P$ are proportional to $C-L$, the costs of disruption of financial intermediation:

$S P=\gamma(C-L)$

Ex ante, expected gains amounts to

$G=s \alpha \frac{1}{1+r}(C-L+S P)=s \alpha \frac{1+\gamma}{1+r}(C-L)$

Gains exceed costs if $G-B>0$, that is if

$G-B=s \alpha \frac{\gamma}{1+r}(C-L)>0$

Whereas the direct benefits from preventing disruption of financial intermediation are exactly offset by the inefficiencies caused by the bubble, it will be rational for central banks to inject liquidity in a crisis whenever there is the risk of spillover effects arising from the disruption of financial intermediation.

\section{Conclusions and Extensions}

The paper modeled the link between financial fragility, asset markets and monetary policy. It showed that central bank's concern about the cost of financial disruption generates an asymmetric response, thus contributing to the creation of an asset price bubble. In an economy with a highly leveraged financial structure, the central bank has an incentive to prevent a "run" on financial intermediation by injecting liquidity when asset values fall significantly. The inflationary side effect of this policy, reducing the real value of nominal debt, is what gives rise to a "put option" for investors. Leveraged investors, rationally anticipating this liquidity injection, drive asset prices above their fundamental values. The paper showed that it is rational for central banks to inject liquidity in a crisis, whenever there is the risk of spillover effects arising from the disruption of financial intermediation. 
The model characterized the central bank's policy, assuming that it has precise control about provision of liquidity. In view of the uncertainty about the transmission mechanism, which is esp. high during a crisis, there may be good reasons to provide even more liquidity than actually needed. So the central banks concern about avoiding the breakdown of the financial system may make it even more cautious to reduce liquidity once the crisis is on retreat. Considering the risk of a severe breakdown, the central bank is likely to err on the safe side. The experience after the crash in 1987 confirms this view. Such an asymmetric response aggravates the moral hazard problem.

This illustrates the need to think about policy alternatives, reducing exposure to financial fragility right from the beginning, and so attacking the problem at its source. Certainly, careful regulation of financial markets is an important step in that direction. One way to reduce exposure is the control of the leverage ratio via margin requirements. Such a policy, however, would come at the cost of rationing investment in the new economy. Whenever the risk of an aggregate shock is small compared to potential benefits of the new economy sector, this option is inferior: Then, provision of aggregate liquidity (anti-deflationary policy) to prevent financial disruption is the superior policy response, even if it comes at the expense of creating a bubble out of moral hazard.

In view of the dominance of bank credit in the Euro area, the risk of disruption of financial intermediation was modeled as a bank run. As Davis (2000) argues, the Diamond/Dybvig (1983) model may also be applied to securities markets. In the same way as runs on banks, there may be runs on security markets. Just like depositors, bond holders have a need for liquidity insurance and so prefer liquid markets. The coordination problem of depositors is simply replaced by a coordination problem among debt holders, so the mechanism worked out in the paper may also be applied to the financial structure in the US. A stock market crash triggering a credit crunch will result in disruption of financial intermediation when the economy is characterized by high debt exposure. Independent of the specific financial structure, the key issue is leverage. Nevertheless, there are significant differences in financial structure. As an example, there is no equivalent to relationship lending in the bond market, and so incentives for restructuring may be quite different; furthermore, contagion effects may work quite differently. Historic evidence seems to suggest that financial fragility is of more serious concern in financial systems based on securities markets. A comparison between the different structures is a promising future research area. 


\section{References:}

Allen, Franklin and Douglas Gale (2000a): “Bubbles and Crises,” Economic Journal

Allen, Franklin, and Douglas Gale (2000b), Optimal Currency Crises, Carnegie Rochester Conference Series (53)1, 177-230

Batini, Nicoletta, and Edward Nelson (2000), When the Bubble Bursts: Monetary Policy Rules and Foreign Exchange Market Behavior, Bank of England, London

Bernanke, Ben S., and Mark Gertler (1999). "Monetary Policy and Asset Price Volatility," in Federal Reserve Bank of Kansas City Economic Review, Fourth Quarter 1999, 17-51.

BIS (2000), Bank for International Settlements $-70^{\text {th }}$ Annual report

Bundesbank (2000), The market for venture capital in Germany, Monthly Bulletin, Frankfurt, October 2000

Cecchetti, Stephen G., Hans Genberg, John Lipski, and Sushil Wadhwani (2000). "Asset Prices and Central Bank Policy." Geneva Reports on the World Economy, ICMB and CEPR, Geneva.

Cogley, Timothy, (1999). "Should the Fed Take Deliberate Steps to Deflate Asset Price Bubbles?," Federal Reserve Bank of San Francisco Economic Review 1, 42-52.

Davis, E Phil (2000), "Financial stability in the Euro area - some lessons from US financial history", LSE Financial Markets Group Special Paper No 123.

Diamond, Douglas /Philip Dybvig (1983), Bank Runs, Deposit Insurance and Liquidity, Journal of Political Economy, Vol. 91 No. 3

Diamond, Douglas/ Rajan, Raghu (2000) A theory of bank capital, Journal of Finance LV, 2431-2465

Dornbusch, Rudi (1999), comment on Bernanke/ Gertler "Monetary Policy and Asset Price Volatility," in Federal Reserve Bank of Kansas City Economic Review, Fourth Quarter 1999, 129-135.

ECB (2000) Asset prices and banking stability, Report prepared by the Banking Supervision Committee, Frankfurt

Greenspan, Alan (1999): "New challenges for monetary policy". Speech at Jackson Hole conference on "New Challenges for Monetary Policy", August 27.

Hackethal, Andreas and Reinhard H. Schmidt (2000), Financing Patterns: Measurement Concepts and Empirical Results, Goethe University of Frankfurt, Working Paper Series: Finance and Accounting

Issing, Otmar (1998), in: Gertler, Mark, Marvin Goodfriend, Otmar Issing and Luigi Spaventa (1998): “Asset prices and monetary policy. Four views". CEPR and BIS.

Miller, Marcus/ Paul Weller/ Lei Zhang (2002), Moral Hazard and US Stock Market: Analysing the "Greenspan Put, University of Warwick, forthcoming in Economic Journal, March 2002.

Schmidt, Reinhard H. / Andreas Hackethal/ Marcel Tyrell (1997), Disintermediation and the Role of Banks in Europe: An International Comparison, working paper Finance, Goethe University Frankfurt

Smets, Frank (1997) Financial Asset Prices and Monetary Policy: Theory and evidence, BIS Working Papers No. 47 


\section{Appendix: Charts and Figures}

\section{Figure 1}

\section{Components of non-financial companies' inter-sectoral liabilities}

$\%$ of total liabilities at market prices

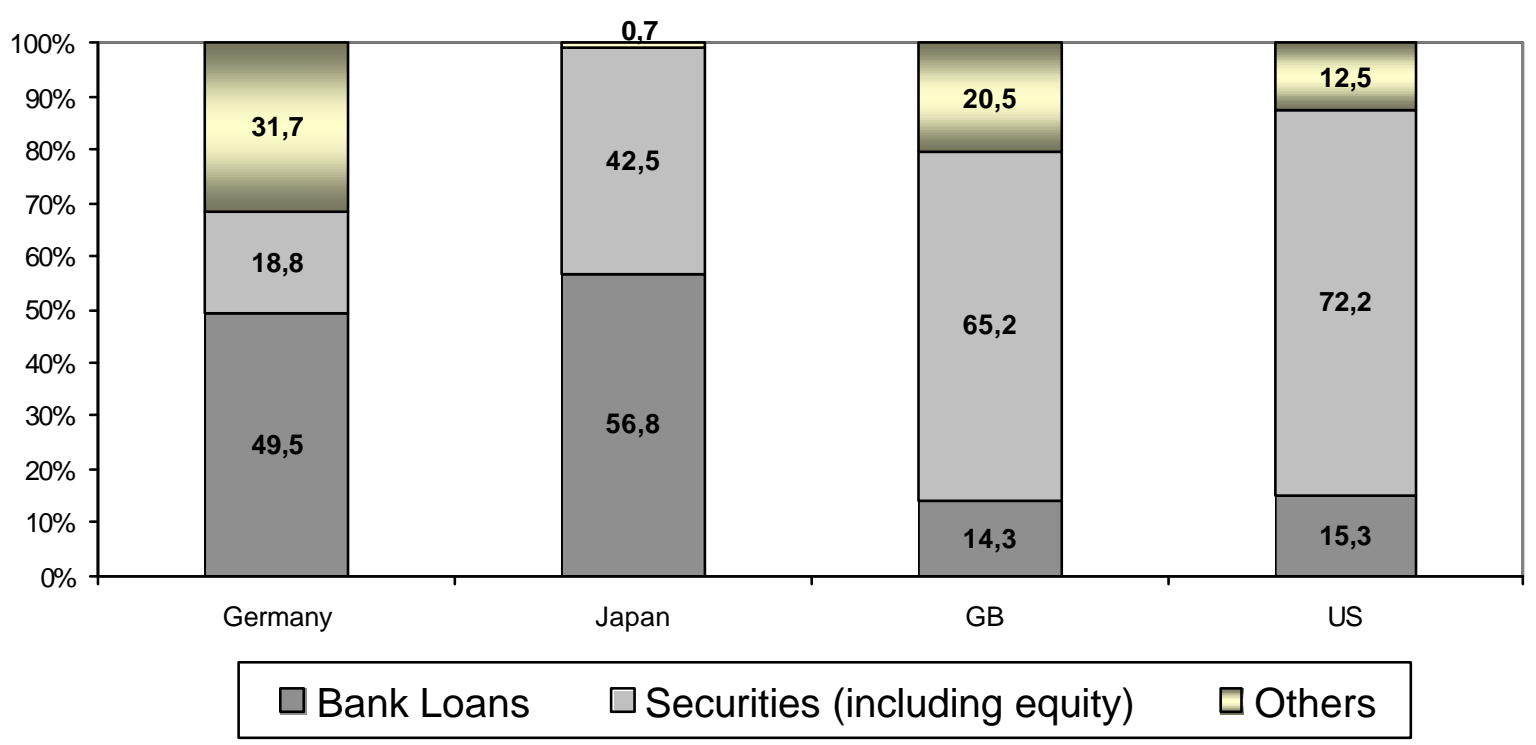

Source: Hackethal/Schmidt (2000)

\section{Figure 2}

\section{Stock market indicators: Euro area versus US}

Market capitalization (bn of US\$) and number of listed stocks

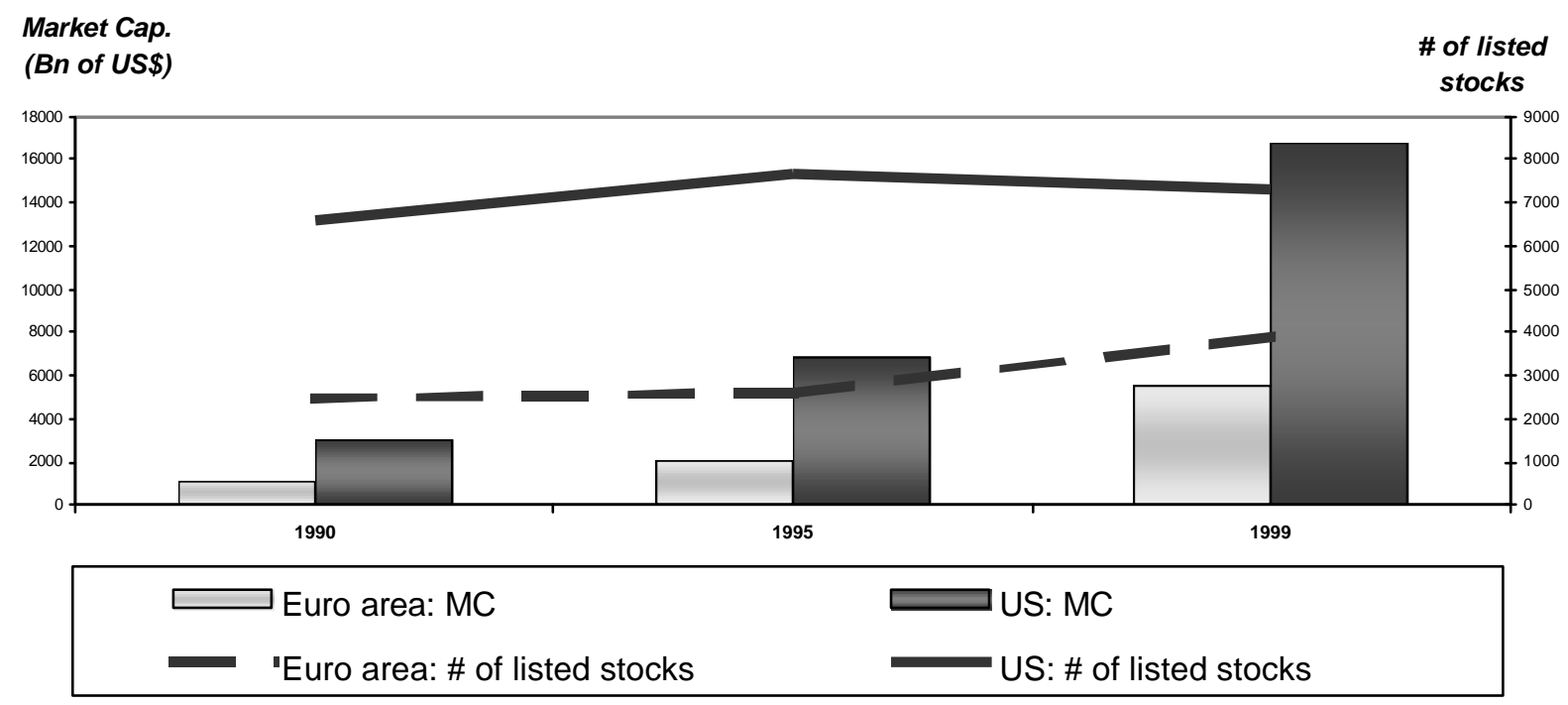

Source: BIS (2000) 
Figure 3

EMU: Selected components of investment of private non-financial sectors $\%$ of GDP

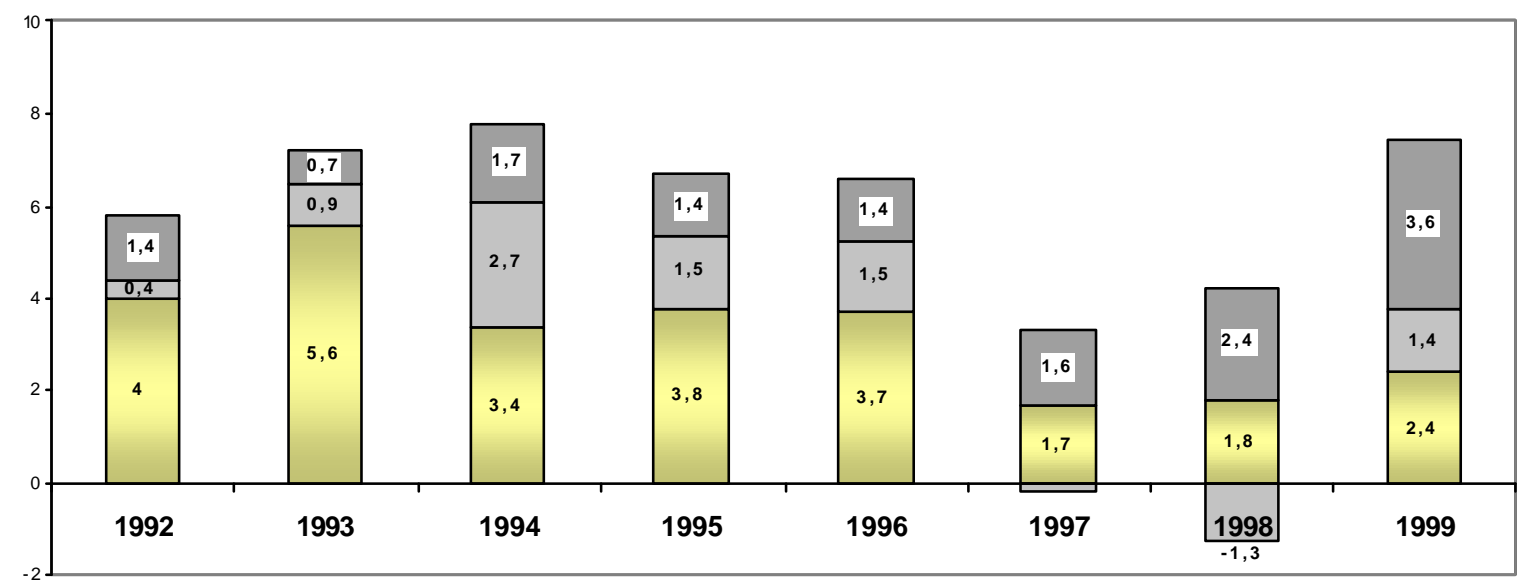

Equity

Securities (excluding equity)

$\square$ Cash and Deposits

Source: ECB (October 2000)

Figure 4

EMU: Selected components of external financing of non-financial sectors $\%$ of GDP
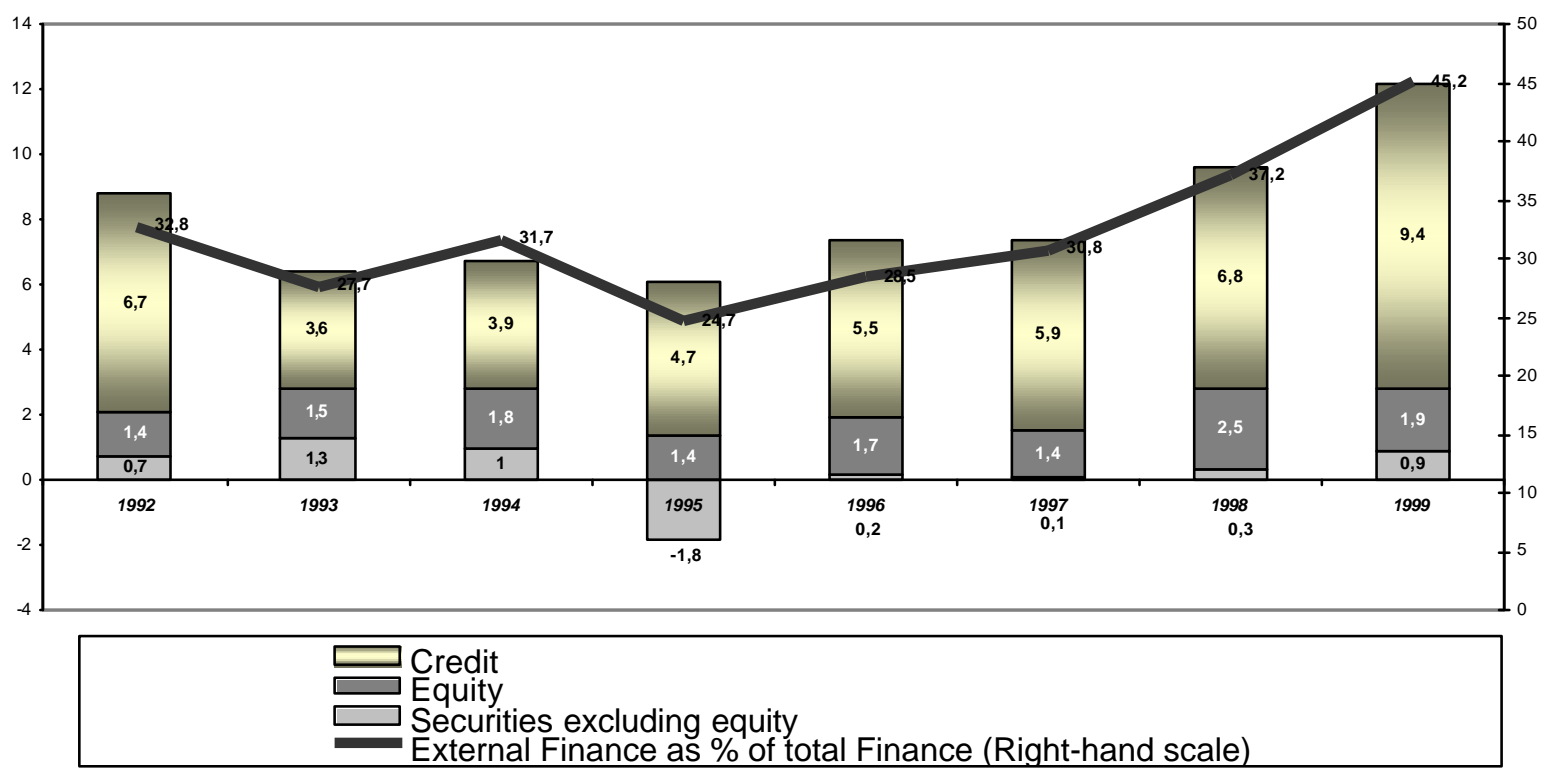

External Finance as \% of total Finance (Right-hand scale)

Source: ECB (October 2000) 
Figure 5

\section{Shareholders in Germany and the US}

$\%$ of total population ${ }^{*}$

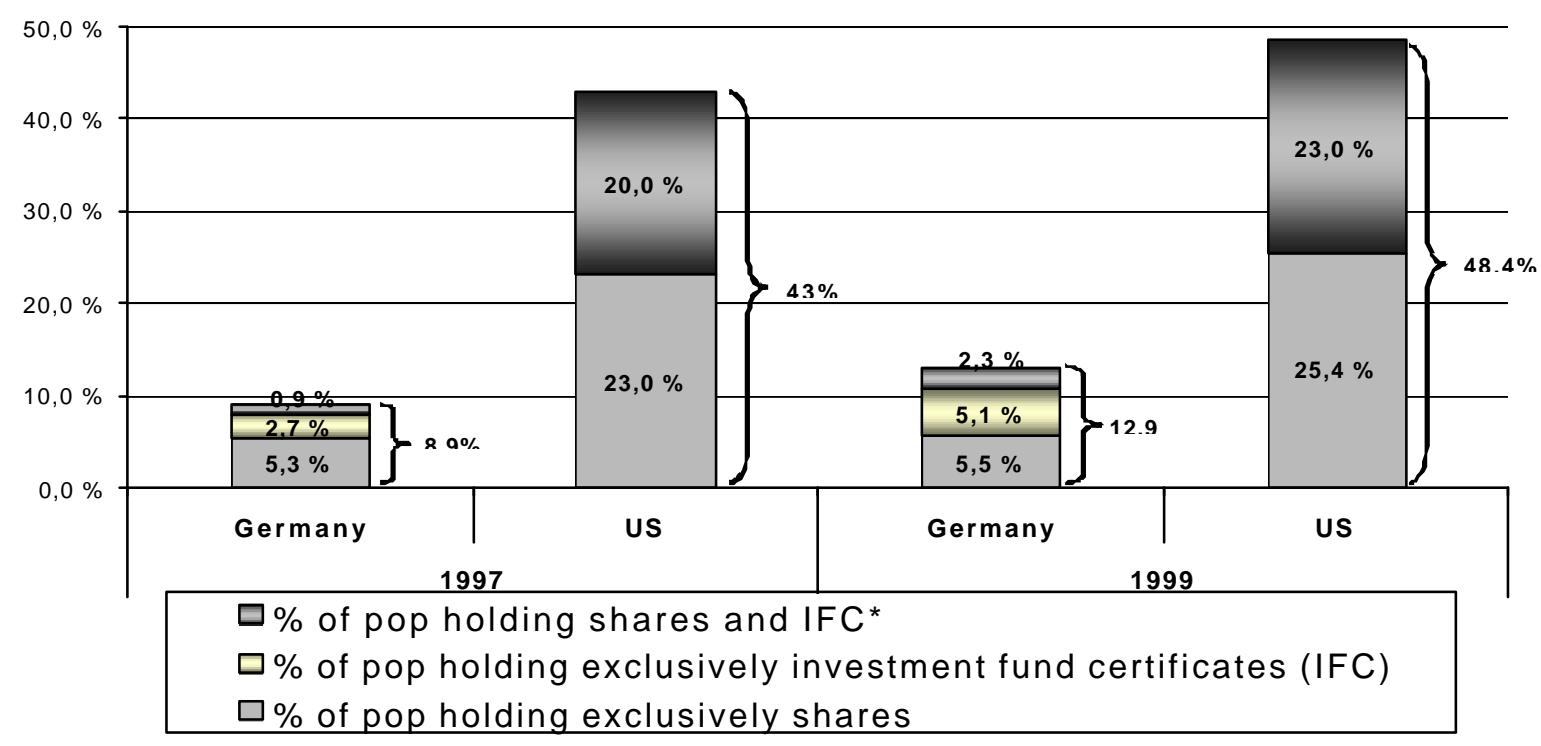

Source: Deutsches Aktieninstitut

Figure 6

\section{Shareholders in Germany}

$\%$ of total population

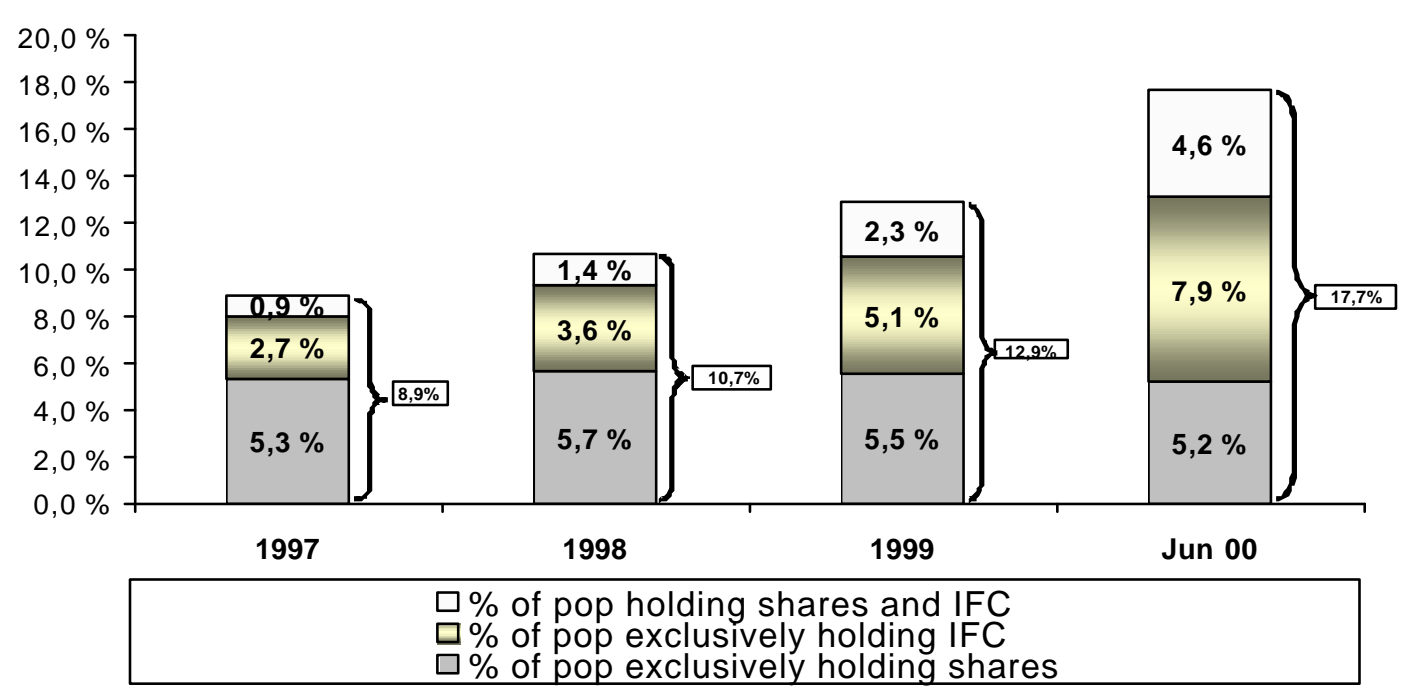

Source: Deutsches Aktieninstitut

\footnotetext{
* Data for US includes individuals exclusively holding shares
} 


\section{FIGURE 7}

Share Prices in Europe and the US

\section{Log of Indices, 01/09/97=100}

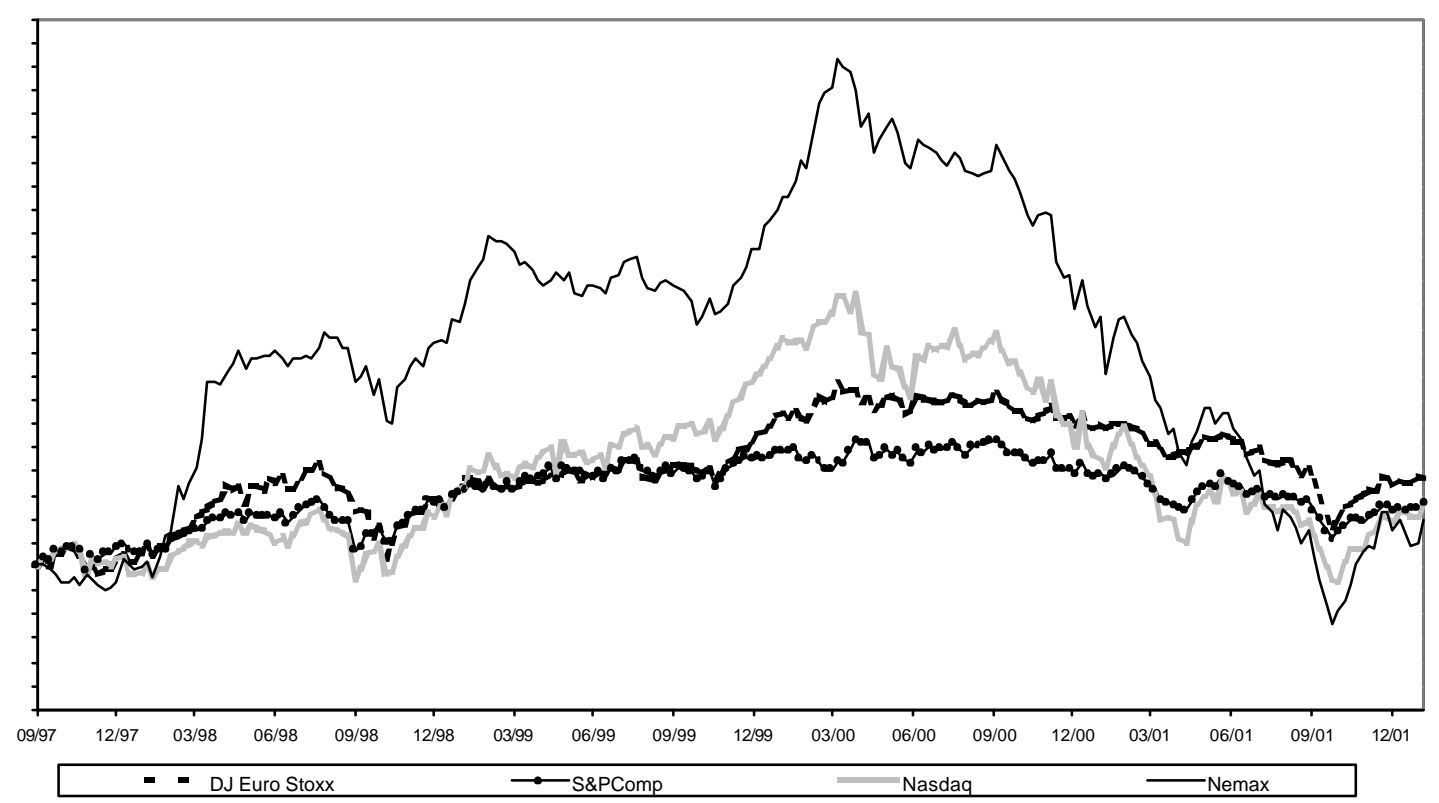

Source: Datastream

\section{FIGURE 8}

Share Prices of Telecom Firms in Europe and the US

\section{Log of Indices, 01/09/97=100}

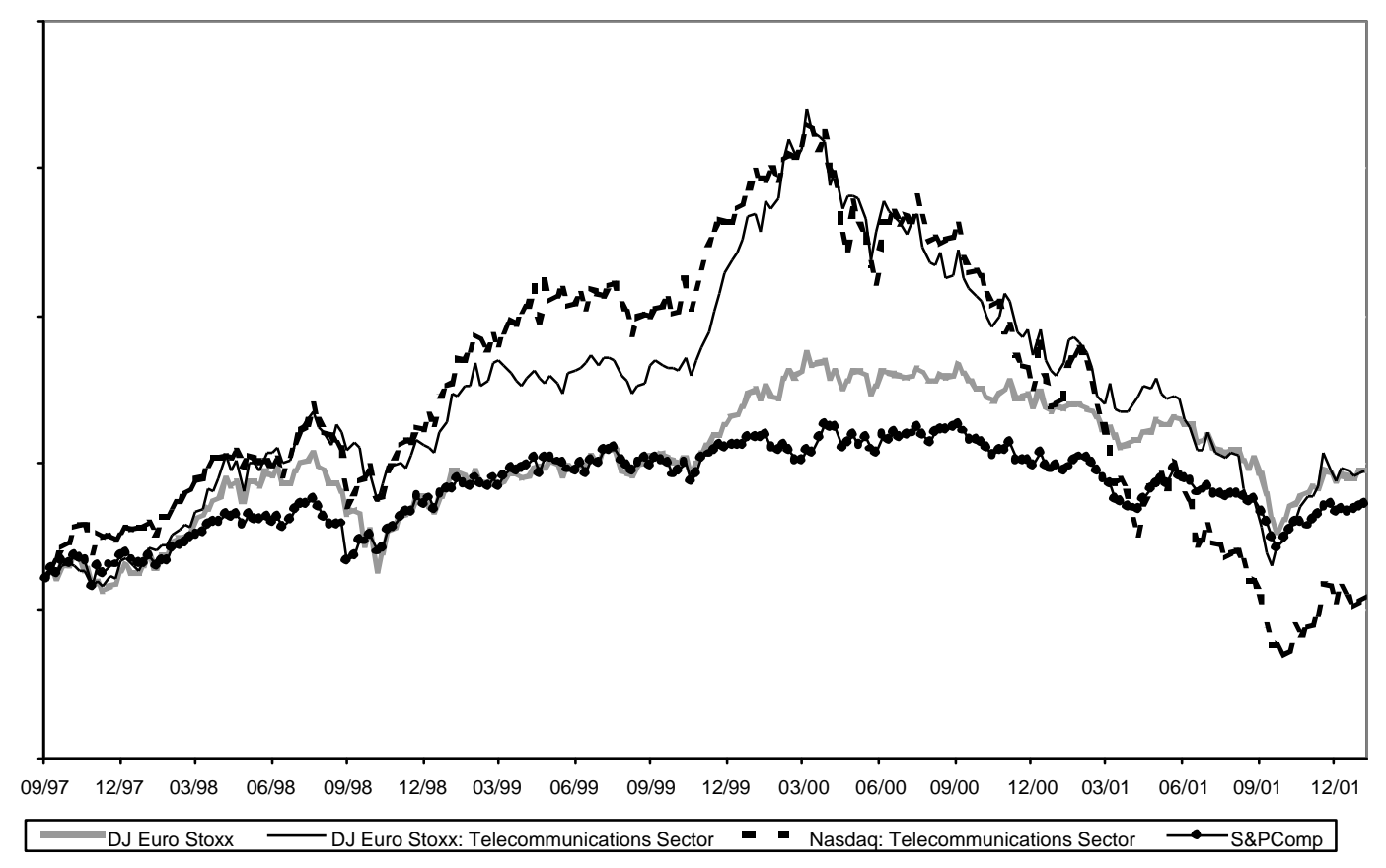

Source: Datastream 
Figure 9

\section{Commercial Real Estate Prices for selected countries (Major Cities)}

Indexes, 1994=100

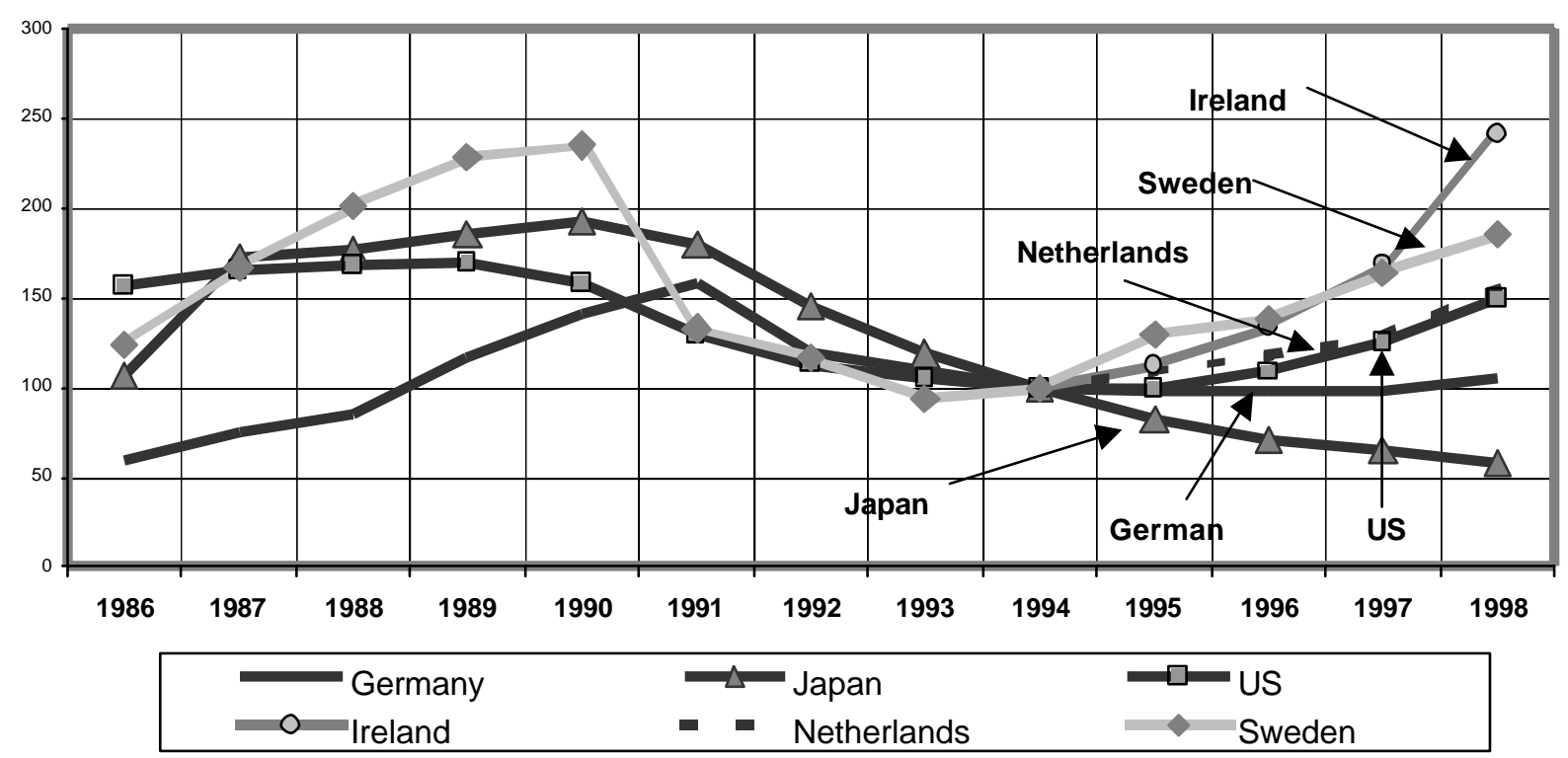

Source: ECB (May 2000) 


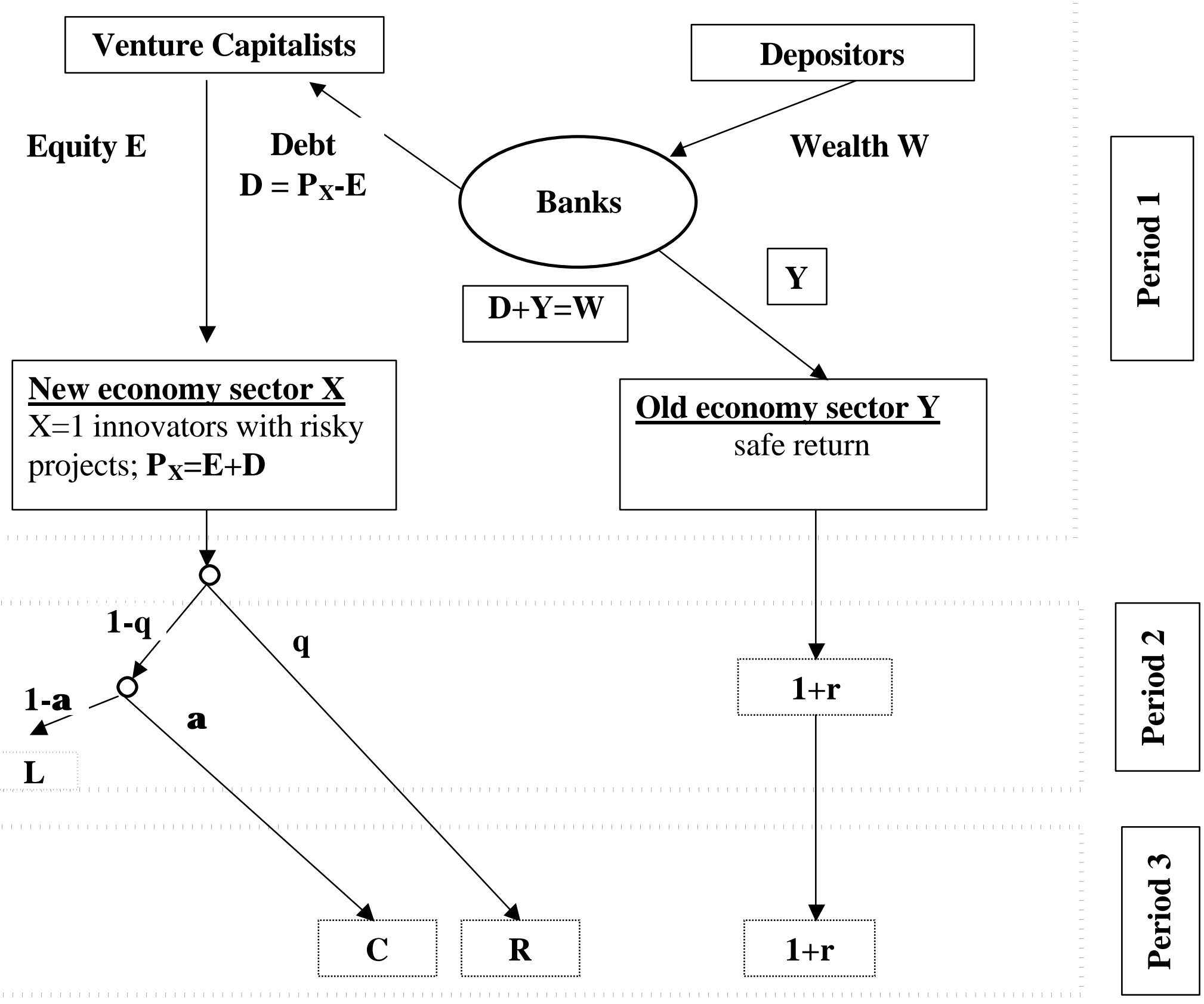

